\title{
Van Gölü'nden Toplanan Su ve Sediment Numunelerinden İzole Edilen Bakterilerin Lakkaz ve Mannanaz Enzimlerini Üretme Kabiliyetleri
}

\author{
Nevroz Aslan Ertaş ${ }^{1 *}$, Erdal Öğün ${ }^{2}$ \\ ${ }^{1}$ Van Yüzüncü Y1l Üniversitesi Moleküler Biyoloji ve Genetik Bölümü, Van, Türkiye (ORCID: 0000-0003-3590-5961) \\ ${ }^{2}$ Van Yüzüncü Yıl Üniversitesi Moleküler Biyoloji ve Genetik Bölümü, Van, Türkiye (ORCID: 000-0001-8280-4245)
}

(İlk Geliş Tarihi 10 Şubat 2020 ve Kabul Tarihi 14 Mart 2020)

(DOI: 10.31590/ejosat.692425)

ATIF/REFERENCE: Aslan Ertaş, N. \& Öğün, E. (2020). Van Gölü’nden Toplanan Su ve Sediment Numunelerinden İzole Edilen Bakterilerin Lakkaz ve Mannanaz Enzimlerini Üretme Kabiliyetleri. Avrupa Bilim ve Teknoloji Dergisi, (18), 545-551.

\begin{abstract}
$\ddot{O} \mathbf{z}$
Bu çalışmanın amacı, Van Gölü'nden toplanan su ve sediment numunelerinden lakkaz ve mannanaz enzimi üretme kabiliyetlerine sahip bakterilerin karakterizasyonudur. Bu araştırmanın materyalini Van Gölü’nden toplanan su ve sediment numuneleri oluşturmuş̧ur. İzolasyon çalışması dilüsyon plak yöntemi ile alkali besiyerinde gerçekleştirilmiştir. İki farklı koloni morfolojisine sahip izolat gözlemlenmiştir. İzolatlara koloni çapı, pigmentasyon, hücre şekli, gram reaksiyonu, indol testi, sitrat testi, voges-proskauer (vp), arabinoz, mannitol, sükroz, adonitol,metil_d-glikozit, selobiyoz, mannoz, salicin, traheloz, galaktoz, inositol, rafinoz, inulin, sorbitol, ksiloz, melesitoz, glikoz, arjinin, nitrat redüksiyonu, beta galaktosidaz, oksidaz, lakkaz enzim aktivitesi, mannanaz enzim aktivitesi, nişasta hidrolizi, tween 80 hidrolizi, skim milk hidrolizi ve ksilan hidrolizi testleri uygulanmıştır. İzolatların lakkaz enzimini üretme kabiliyetlerine $\% 0.2 \mathrm{mM}$ ABTS ve $\% 0.1 \mathrm{mM} \mathrm{CuSO} 4$ ile bakılmıştır. Mannanaz enzimi üretme kabiliyetleri \%1 mannoz ve fenol içeren alkali besiyeri kullanılarak belirlenmiştir. Genomik DNA'sı izole edilen 2 izolatın 16S rRNA gen bölgesi 27F ve 1492R evrensel primerleri ile amplifiye edilip sekans analizi yapılmıştır. Mega 7.0.18 paket programı ile Maksimum Olabilirlik algoritması seçilerek Jukes ve Cantor'un uzaklık matrisi ile filogenik ağaçlar oluşturulmuştur. İzolatların tümünün lakkaz enzimi yönünden negatif olduğu, mannanaz enzimi yönünden N1 ve N2 izolatlarının pozitif olduğu görülmüştür. N1 izolatı için oluşturulan filogenetik ağaçta Halomonas bakterileri kendi aralarında güçlü bir homoloji ile kümelenmiştir. N2 izolatı için oluşturulan filogenetik ağaçta Bacillus bakterileri genel olarak güçlü bir homoloji ile kümelenmiş̧ir. N1 ve N2 izolatları, morfolojik, fizyolojik, biyokimyasal özelliklerine ve 16S rRNA gen bölgesi analizine göre N1 Halomonas stevensii ve N2 Bacillus agaradhaerens olarak teşhis edilmiştir.
\end{abstract}

Anahtar Kelimeler: 16S rRNA, lakkaz, mannanaz.

\section{The Production Capabilities of Laccase and Mannanase Enzymes of The Bacteries Isolated from Water and Sediment Samples Collected from The Van Lake}

\begin{abstract}
The aim of this study is the characterization and diagnosis of bacteria that have the ability to produce laccase and mannanase enzymes from water and sediment samples collected from Lake Van. The material of this research were form water and sediment samples collected from Van Lake. The isolation study was carried out on the alkali medium by dilution plate method. Isolate with two different colony morphologies were observed. Colony diameter, pigmentation, cell shape, gram reaction, indole test, citrate test, voges-proskauer (vp), arabinose, mannitol, sucrose, adonitol, methyl_d-glycoside, cellobiosis, mannose, salicin, trahelosis, galactose, inositol, rafinose, inulin, sorbitol, xylose, melesitose, glucose, arginine, nitrate reduction, beta galactosidase, oxidase, laccase enzyme activity, mannanase enzyme activity, starch hydrolysis, tween 80 hydrolysis, skim milk hydrolysis and xylan hydrolysis tests have made. The ability of isolates to produce laccase enzyme was evaluated with $0.2 \% \mathrm{mM}$ ABTS and $0.1 \% \mathrm{mM} \mathrm{CuSO}$. Their ability to produce mannanase enzyme was determined using an alkaline medium containing 1\% mannose and phenol. 16S rRNA gene region of 2 isolates whose


genomic DNA was isolated were amplified with universal primers of 27F and 1492R and sequence analysis was performed. Phylogenic trees were created with the distance matrix of Jukes and Cantor by selecting the Maximum Likelihood algorithm with the Mega 7.0.18 package program. It was observed that all of the isolates were negative in terms of laccase enzyme and N1 and N2 isolates were positive in terms of mannanase enzyme. In the phylogenetic tree created for N1 isolate, Halomonas bacteria was clustered with a strong homology among themselves. Bacillus bacteria were generally clustered with a strong homology in the phylogenetic tree created for $\mathrm{N} 2$ isolate. $\mathrm{N} 1$ and $\mathrm{N} 2$ isolates were diagnosed as N1 Halomonas stevensii and N2 Bacillus agaradhaerens according to their morphological, physiological, biochemical properties and 16S rRNA gene region analysis.

Keywords: 16S rRNA, laccase, mannanase.

\section{Giriş}

Van Gölü, Dünya üzerindeki dördüncü en büyük su kütlesidir (hacim 607 km3, alan 3570 km2, maksimum derinlik 450 m, gö1 seviyesi deniz seviyesinden $1648 \mathrm{~m}$ yüksekliktedir). $\mathrm{pH}$ oran1 9.7-9.8 ve tuzluluk oranı $\% 021.7$ olan yeryüzündeki en büyük soda gölü olarak da bilinir (Berber ve Yenidünya, 2005). Van Gölü, dünyadaki bilinen en büyük mikrobiyalitleri barındırır (Kepme ve ark., 1991). Kış konveksiyonundan dolayı, göl suyunun kimyasal bileşimi gölde homojendir. Farklı kompozisyonlardaki suları getirmelerine rağmen, nehirler alkalin toprak metallerinden daha büyük miktarda bikarbonat tüketirler. Bu soda kimyası postvolkanik CO2 aktivitesine atfedilebilir (Degen ve ark.,1984). Van Gölü ile yapılan bu tür çalışmalar neredeyse yok denecek kadar azdır.

Enzim kaynağı olarak mikroorganizmaların tercih edilmesinin nedenleri; yan ürün oluşturmalarının az olması, aktivitelerinin yüksek olması, daha ekonomik olması, stabiliteye sahip olması, yüksek oranlarda ve saflıkta üretilebilmeleridir (Wiseman, 1987; Horikoshi, 1999; Khalikova ve ark., 2019). Mikroorganizmalardan elde edilen enzimlerin tüm dünya genelinde yıllık kullanım oranlarına bakıldı̆̆ında $\% 25$ alkalin proteaz, $\% 21$ diğer proteazlar, $\% 18$ amilaz, $\% 10$ renin, $\% 3$ tripsin, $\% 3$ lipaz ve $\% 10$ diğer karbonhidrat parçalayan enzimler (selülaz ve ksilanaz gibi), \%10 kadar ise analitik ve farmasötik enzimlerin olduğu şeklinde bir dağılım belirlenmiştir (Rao ve ark., 1998). Enzimatik oksidasyon teknikleri hamur ve kağıt, tekstil ve gıda endüstrileri gibi çok çeşitli endüstriyel alanlarda potansiyele sahiptir.

Lakkaz enzimi, gıda, kozmetik, kağıt, tekstil ve tekstil atıklarının azo boya içeren sularının biyolojik arıtılması yaygın bir şekilde kullanılır (Arık ve ark., 2008; Chandra ve Chowdhary, 2015; Demiralp ve ark., 2015). Lakkaz birçok canlı tarafindan kullanılan bir enzimdir. Yüksek bitkilerde ve mantarlarda yaygın olarak bulunur. Fungusların Ascomycetes, Deuteromycetes ve Basidiomycetes sinıflarında ve ligninolitik beyaz-çürükçül mantarlarda bu enzim, bol miktarda bulunur (Shekher ve ark., 2011). Lakkaz enzimi, funguslara ilave olarak birçok gram negatif, gram pozitif bakteriler ve aktinomycetler tarafindan da üretilmektedir(Singh ve ark., 2011).

$\beta$-mannanazlar (EC 3.2.1.78), mannanlar, galaktomannanlar, glukomannanlar ve galaktoglukanetnamelerde 1,4-beta-D-mannozidik bağları hidroliz eden hücre dışı enzimlerdir. Mannanlar ve heteromannanlar, sert ağaçlar ve yumuşak ağaçlar, baklagil bitkilerinin tohumları ve fasulyelerde hemiselüloz fraksiyonunun bir parçası olarak doğada yaygın olarak bulunurlar. Mikroorganizmalar mannanazların en güçlü üreticileri olup hızlı büyümeleri, yetiştirme için sınırlı alan ve genetik manipülasyona hazır erişim açısından tercih edilen enzim kaynaklarını temsil etmektedir. (Dhawan ve Kaur, 2007). Beta-Mannanazlar, gıda, yem ve kağıt endüstrisinde ve kağıt endüstrisinde çok sayıda uygulamaya sahiptir. Mannanazlar, çeşitli mantar, maya, bakteri ve deniz yosunları ile karasal bitkilerin çimlenmekte olan tohumlarından ve çeşitli omurgasızlardan üretilebilir. Bu seçenekler arasında, düşük maliyet, yüksek üretim hızı ve kolayca kontrol edilen koşullar nedeniyle beta-mannanazların mikroorganizmalar tarafından üretilmesi daha umut vericidir (Feng ve ark., 2003). Beta-mannanaz, sanayinin birçok alanında kullanılan çok umut verici bir enzim olduğu için, işlemlerden daha yüksek verim elde etmek ve süreçlerin süresini azaltmak için mannanaz üretiminin arttırılması gerekir; böylece, enzimi optimize etmek için ekonomik bir üretim sağlanabilir.

\section{Materyal ve Metot}

\subsection{Su ve Sediment örneklerinin toplanması}

Van Gölü'den alınan sediment örnekleri 1000ml'lik steril polietilen torbalar içerisinde, su örnekleri ise steril $300 \mathrm{ml}$ 'lik cam şişelere bırakılarak toplandı ve 12 saat içerisinde laboratuvara ulaştıııldı.

\subsection{Su ve sediment örneklerinden alkalifilik bakterilerin izolasyonu}

Sediment örneklerinden Ringer Solusyonu içerisinde 1/10'luk çözelti hazırlandı. Hazırlanan sediment çözeltisinden dilüsyon

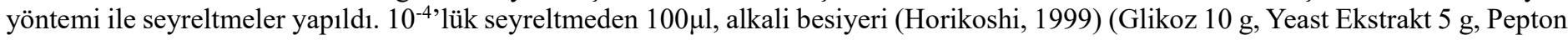
$5 \mathrm{~g}, \mathrm{KH}_{2} \mathrm{PO}_{4} 1 \mathrm{~g}, \mathrm{MgSO}_{4}$ X $7 \mathrm{H}_{2} \mathrm{O} 0.2 \mathrm{~g}, \mathrm{Na}_{2} \mathrm{CO}_{3} 10 \mathrm{~g}$, Agar $15 \mathrm{~g}$, ddH $\mathrm{d}_{2} \mathrm{O} 1000 \mathrm{ml}$ ) içeren petri plaklarının yüzeyine eğri cam çubuk yardımıyla yayıldı. Petri kapları $30^{\circ} \mathrm{C}$ 'de 48 saat inkübasyona bırakıldı. İnkübasyonu müteakip elde edilen karışık kültürlerden, saf kültürler elde edildi. Saf kültürlerden stok kültürler hazırlandı ve daha sonraki aşamalarda kullanılmak üzere içerisinde $\% 5$ oranında gliserol bulunan kriyojenik tüpler içerisinde $-20^{\circ} \mathrm{C}$ 'de muhafaza edildi.

\subsubsection{Lakkaz enzimi üreten izolatların belirlenmesi}

İzolatlar, içerisinde $\% 0.2 \mathrm{mM} \mathrm{ABTS}$ ve $\% 0.1 \mathrm{mM} \mathrm{CuSO}_{4}$ bulunan alkali besiyeri plaklarına yoğun bir şekilde ekildi. Petri plakları $30^{\circ} \mathrm{C}$ 'de 48 saat inkübasyona bırakıldı. İnkübasyonu müteakip ABTS'yi oksitleyen izolatların çevresinde yeşil renkli halelerin varlığı, lakkaz enzimi üretimi yönünden, pozitif olarak değerlendirildi (Soden ve ark., 2002; Öğ̈n ve ark., 2018). 


\subsubsection{Mannanaz enzimi üreten izolatların belirlenmesi}

Mannanaz aktivitesi için, alkali besiyeri içerisine \%1 mannoz ve fenol red ilave edildi. İzolatlar öze yardımı ile besiyerine yoğun şekilde ekildi. Petri kapları $30^{\circ} \mathrm{C}^{\prime}$ de 72 saat inkübasyona bırakıldıktan sonra incelendi. Üreme bölgelerinin etrafındaki sarı zonlar mannanaz aktivitesi yönünden pozitif olarak değerlendirildi.

\subsubsection{Lakkaz ve Mannanaz enzimi üreten izolatların identifikasyonu}

Mikroorganizma veya mikroorganizma gruplarının kendilerine has bir biyokimyasal özelliği vardır. Bakteriler için örnek verecek olursak; her bakteri kendine özgü enzimlere sahip olup, belirli maddeleri yine kendine özgü bir biçimde metabolize ederek, çeşitli yıkım ve yapım ürünleri meydana getirmektedir. Bakterilerin bu özelliklerinin tek tek veya listeler halinde çeşitli kaynaklarda (kitap, araştırma makalesi, derleme vb.) bulmak mümkündür. Ancak bu konu başvurulacak temel kaynak Bergey's Manual of Systematic Bacteriology dir. Bergey's Manual, doğadaki bilinen bakterilerinin tümünü, belli taksanomik gruplar halinde inceleyerek, biyokimyasal özellikleri de dahil olmak üzere, pek çok özelliğini tek tek ve liste halinde açıklamaktadır.

Bakteriyel izolatların morfolojik, fizyolojik ve biyokimyasal özelliklerinin belirlenmesinde Bergey's Manual of Systematic Bacteriology eserinin ikinci cildi referans alındı (George ve ark., 2005; Öğün ve ark., 2018a).

\subsection{Moleküler karakterizasyon}

\subsubsection{Genomik DNA izolasyonu}

Genomik DNA izolasyonu için, alkali besiyeri içerisinde $30^{\circ} \mathrm{C}^{\prime} \mathrm{de} 48$ saat inkübe edilen kültürler $2 \mathrm{dk}$ santrifüj edildi. Bakterilerden genomik DNA izolasyonu için Ausubel ve ark. (1994), metodu modifiye edilerek kullanıldı (Awla ve ark., 2017).

\subsubsection{Polimeraz zincir reaksiyonu uygulamast}

16S rRNA gen bölgesinin yaklaşı 1450 bazlık bölgesi uygun üniversal primerler kullanılarak polimeraz zincir reaksiyonu (PCR) ile amplifiye edildi. $\mathrm{Bu}$ amaçla bakteria domaini için spesifik $27 \mathrm{~F}$ ve $1492 \mathrm{R}$ universal primerleri kullanıldı. PCR karışımı, $50 \mu \mathrm{l}$ polimeraz tampon içerisinde her tampondan 30 pikomol, kromozomal DNA'dan $10 \mathrm{ng}$ ve $200 \mu \mathrm{M}$ dNTPs ve 2.5 ünite Taq polimeraz içerecek şekilde hazırlandı. Tüm amplifikasyon koşulları $94^{\circ} \mathrm{C}$ 'de 5 dakikalık ön denatürasyon, $94^{\circ} \mathrm{C}$ 'de 30 sn denatürasyon, $50{ }^{\circ} \mathrm{C}$ 'de 30 sn bağlanma ve $72{ }^{\circ} \mathrm{C}$ 'de 10 sn uzamadan oluşan 30 döngü lükamplifikasyon ve $72{ }^{\circ} \mathrm{C}$ 'de 15 dakikalık final uzamadan oluşacak şekilde programlandı. PCR işlemi tamamlandıktan sonra, PCR karışımının bir kısmı, agaroz jel elektroforezi kullanılarak görüntülendi (Nikiforov ve Howles, 2001; Öğ̈̈n ve ark., 2018b).

\subsubsection{S rRNA gen bölgesinin dizi ve filogenetik analizi}

16S rRNA gen bölgesi dizileme sonuçları Codon Code Aligner V.6.0.2 programı ile her suş için kromatogramlar tek tek incelenmiş ve zayıf nitelikli baz dizilerinin (belirsiz yani ' $N$ ' kodlu birkaç baz) genellikle sekans başları ve sonlarındaki bölgelerinde kesilerek uzaklaştıılmış ve contiqler oluşturulmuştur. NCBI'da blast yapılarak her suşa yakın türlerin access kodları alınarak, hem veri tabanındaki yakın türlerle hem de kendi aralarında analiz edilmiştir. Daha sonra ClustalW programı ile korunmuş bölgeler kıyaslanarak, Mega7 programında Maximum Likelihood algaritmasında Jukes-Cantor metodu seçilmiş, Maksimum Likelihood filogenetik ağaçı oluşturulmuş ve izolatların evrimsel açıdan filogenetik pozisyonları belirlenmiştir (Sharef ve ark., 2018).

\section{Araştırma Sonuçları ve Tartışma}

\subsection{Su ve sediment örneklerinden alkalifilik bakterilerin izolasyonu}

Van Gölü'den toplanan su ve sediment örneklerinden, yapılan izolasyon çalışmalarında iki farklı koloni morfolojisine sahip izolat gözlendi. Seçilen bu izolatlardan biri gram negatif, diğerinin ise gram pozitif bakteri olduğu belirlendi.

\subsubsection{Lakkaz ve Mannanaz enzimi üreten izolatların belirlenmesi}

Mezofilik organizmalardan izole edilen enzimler, esasen dar bir $\mathrm{pH}$, sıcaklık ve iyonik güç aralığında işlev görür ve bu da endüstriyel koşulları zorlayan teknolojik uygulamalarını zorlaştııı. Bu nedenle, asidite, alkalinite, tuzluluk, sıcaklık veya basınç aşırılıkları gibi zorlu çevresel koşullarda başarılı olabilen mikroorganizma aramak için kayda değer çabalar sarf edilmiştir. Ekstremofiller olarak adlandırılan bu mikroorganizmalar, aşırı koşullar altında işlev gören ve bu nedenle de büyük bir biyoteknolojik vaatte bulunan yeni enzimlerin değerli bir kaynă̆ıdır (Van den Burg, 2003).

Enzimler, endüstride hemen her alanda kullanılabilmekte ve bu alanların sayısı gün geçtikçe artmaktadır. Bu nedenle birçok bilim adamı doğal kaynaklardan bakteri izolasyonuna gitmekte, böylelikle yeni türlerin ortaya çıkması sağlanmaktadır (Awla ve ark., 2017).

İzole edilen iki izolat mannanaz enzimi yönünden pozitif bulundu. Halomonas N1 ve Bacillus N2 izolatı olarak adlandırıldı (Şekil1). İzolatların ikiside lakkaz enzimi üretme yönünden negatif sonuç vermiştir. 



Şekil 1. N1 ve N2 izolatının mannanaz aktivitesi

\subsubsection{Lakkaz ve Mannanaz enzimi üreten izolatların identifikasyonu}

Bu izolatların morfolojik, fizyolojik ve biyokimyasal ve moleküler özellikleri belirlendi. İndol, oksidaz, katalaz, skim milk hidrolizi (Proteaz), tween80 hidrolizi (lipaz), nisaşta hidrolizi (amilaz), ksilan hidrolizi (Ksilanaz), nitrat redüksiyonu, sitrat kullanımı, Voges Proskauer (VP), beta galaktosidaz, lakkaz aktivitesi, mannanaz aktivitesi ve bazı şekerlerin kullanımı ile ilgili biyokimyasal özellikleri tespit edildi (Tablo 1). Çalışmamızda izolatların ikisi de mannanaz enzimi üretme kabiliyeti gösterdiğinden endüstriyel açıdan önemli olduğu belirlenmiştir. Yine N1 ve N2 izolatının nitratı indirgemesi pozitif olması yönüyle önemli bulundu. Bu durum alkali habitatlarda azot döngüsünün gerçekleştiğinin göstergesidir.

Tablo 1. N1 ve N2 izolatlarina uygulanan biyokimyasal testler

\begin{tabular}{|c|c|c|c|}
\hline No & Testler & N1 & N2 \\
\hline 1 & Koloni çap1 & $2 \mathrm{~mm}$ & $2 \mathrm{~mm}$ \\
\hline 2 & Pigmentasyon & Krem & Krem \\
\hline 3 & Hücre şekli & Basil & Basil \\
\hline 4 & Gram reaksiyonu & - & + \\
\hline 5 & İndol testi & - & - \\
\hline 6 & Sitrat testi & + & + \\
\hline 7 & Voges-Proskauer (VP) & - & - \\
\hline 8 & Arabinoz & - & - \\
\hline 9 & Mannitol & - & - \\
\hline 10 & Sükroz & + & - \\
\hline 11 & Adonitol & - & - \\
\hline 12 & Metil_D-Glikozit & - & - \\
\hline 13 & Selobiyoz & - & - \\
\hline 14 & Mannoz & + & + \\
\hline 15 & Salicin & - & - \\
\hline 16 & Traheloz & + & - \\
\hline 17 & Galaktoz & - & - \\
\hline 18 & İnositol & - & - \\
\hline 19 & Rafinoz & - & - \\
\hline 20 & İnulin & - & - \\
\hline 21 & Sorbitol & - & - \\
\hline 22 & Ksiloz & - & - \\
\hline 23 & Melesitoz & - & - \\
\hline 24 & Glikoz & + & + \\
\hline 25 & Arjinin & + & + \\
\hline 26 & Nitrat Redüksiyonu & + & + \\
\hline 27 & Beta galaktosidaz & + & + \\
\hline 28 & Oksidaz & + & + \\
\hline 29 & Lakkaz enzim aktivitesi & - & - \\
\hline 30 & Mannanaz enzim aktivitesi & + & + \\
\hline 31 & Nişasta hidrolizi & - & - \\
\hline 32 & Tween 80 hidrolizi & - & - \\
\hline 33 & Skim milk hidrolizi & - & - \\
\hline 34 & Ksilan Hidrolizi & - & - \\
\hline
\end{tabular}




\subsubsection{S rRNA gen bölgesinin dizi ve filogenetik analizi}

Moleküler yöntemlerden biri olan 16S rRNA gen dizileme bakteriler arasındaki filogenetik ilişkilerin açıklanmasında, herhangi bir ortamdan izole edilen bakterilerin tanımlanmasında kullanılan güçlü bir tekniktir (Busse ve ark., 1996). 2000'li yıllardan itibaren PCR kullanımının ve DNA dizilemenin yaygınlaşmasının sonucu olarak 16S rRNA gen bölgesinin dizilenmesi bakteriyal izolatların doğru şekilde tanımlanmasında ve yeni bakteriyal izolatların literatüre kazandırılmasında büyük öneme sahip olmuştur. 16S rRNA gen bölgesi tüm türlerin tanımlanmasında oldukça faydalı ve korunmuş bölgelerin ise tür için spesifik bilgi verici özelliğe sahip olduğu belirlenmiştir (Brown-Elliott, 2006; Chen ve ark., 2019).

Test organizmaları ve ilgili cinslerin tip türlerinin dizi analizine bağlı filogenetik dendrogramları Maximum Likelihood algoritması kullanılarak oluşturuldu. Maximum Likelihood algoritması için filogenetik uzaklık matriksi Jukes-Cantor metodu izlenerek gerçekleştirildi (Jukes ve Cantor, 1969). Filogenetik analizler için oluşturulan filogenetik ağaçların bootstrap analizleri 1000 tekrarlı olarak MEGA 7 (Kumar ve ark., 2008) paket programında gerçekleştirildi. Evrimsel açıdan korunmuş nükleotid baz dizilerinde ki polimorfizim oranları yardımı ile türler arası uzaklık-yakınlık analizlerinin yapılabilmesi için bootstrap değeri hesaplanmıştır. Şekil 2 ve Şekil 3'de 16S rDNA dizi verileri kullanılarak gerçekleştirilen ML analizlinde her iki izolat için oluşturulan filogenetik ağaçta diş gruplar tamamen farklı bir dal oluşturarak kümelenmiştir.

N1 izolatını filogenetik dendrogramında Halomonadaceae familyasının bir üyesi olan Salinicola halophilus suşu dış grup olarak kullanıldı. Halomonas grubunu temsil eden çalışma izolatı ve ilgili tip türlerinin 16S rRNA nükleotit dizileme analizleri sonucu Maximum Likelihood matriksiyle oluşturulan filogenetik ağaç Şekil 2'de verilmiştir. Oluşturulan filogenetik ağaçta Halomonas cinsi üyeleri ve N1 izolatı kendi aralarında güçlü bir homoloji ile kümelenmiştir. N1 izolatı, Gen Bankası'nda kayıtlı Halomonas stevensii türleri ile sıkı bir şekilde kümelenme göstermiştir.

N1 izolatının BLAST sonucu \%99 Halomonas stewensii olması ve bu türün yeni olması nedeniyle daha önceki çalışmalarla karşılaştırılmıştır. Bu suş için Kim ve arkadaşlarının (2010) yapmış olduğu çalışmadaki sonuçlar ile bizim çalışmamızdaki sonuçlar büyük oranda paralellik göstermiştir. Ancak çalışmamızdaki Tween 80 hidroliz testi ve inositol testi Kim ve arkadaşlarının (2010) yaptığ1 çalışmanın aksine negatif sonuç göstermiştir.

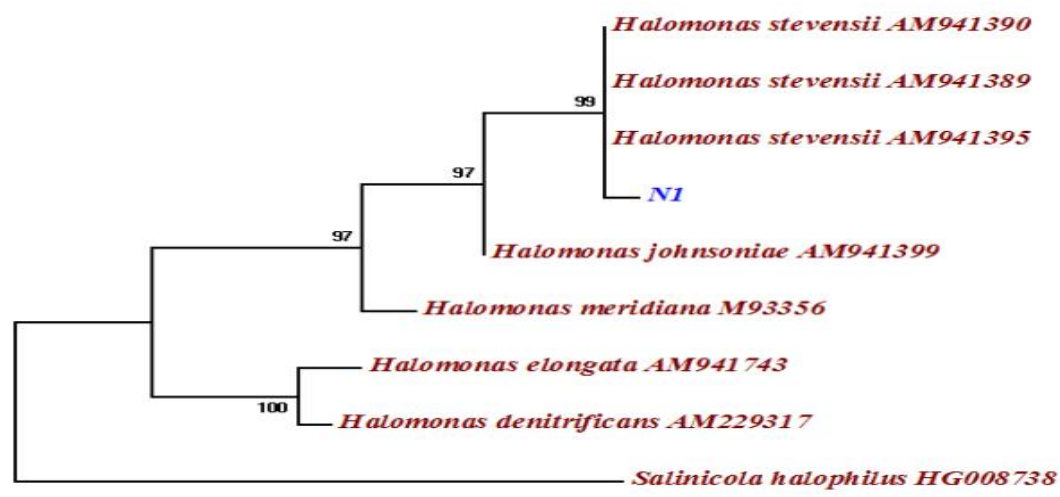

Salinicola halophilus HGO08738



Şekil 2. Maksimum Likelihood (ML) yöntemine göre N1 izolatı için 16S rRNA gen dizilerine dayanan filogenetik ağaç.

N2 izolatını filogenetik dendrogramında Staphylococcus aureus suşu dış grup olarak kullanıldı. Bacillus grubunu temsil eden çalışma izolatı ve ilgili tip türlerinin 16S rRNA nükleotit dizileme analizleri sonucu Maximum Likelihood matriksiyle oluşturulan filogenetik ağaç Şekil 3'de verilmiştir. Oluşturulan filogenetik ağaçta Bacillus cinsi üyeleri ve N2 izolatı kendi aralarında güçlü bir homoloji ile kümelenmiştir. N1 izolatı, Gen Bankası'nda kayıtlı Bacillus agaradhaerens türleri ile güçlü bir homoloji kümelenmiştir. Bacillus'ların oluşturduğu kümelenmede izolatlar kendi aralarında 2 farklı alt gruba ayrılmıştır. Bu alt grupların birincisinde Bacillus agaradhaerens üyeleri ve N2 izolatı kendi aralarında kümelenirken Bacillus selenitireducens, Bacillus saliphilus ve Bacillus neizhouensis suşları kendi aralarında kümelenmiştir.

N2 izolatının BLAST sonucu \%99 Bacillus agaradhaerens olması nedeniyle daha önceki çalışmalarla karşılaştırılmıştır. Bu suş için İbrahim ve arkadaşlarının (2016) yapmış olduğu çalışmada bu suş proteaz aktivitesi yönünden pozitif sonuç gösterirken çalışmamızda ise sonuç negatif olarak belirlenmiştir. 


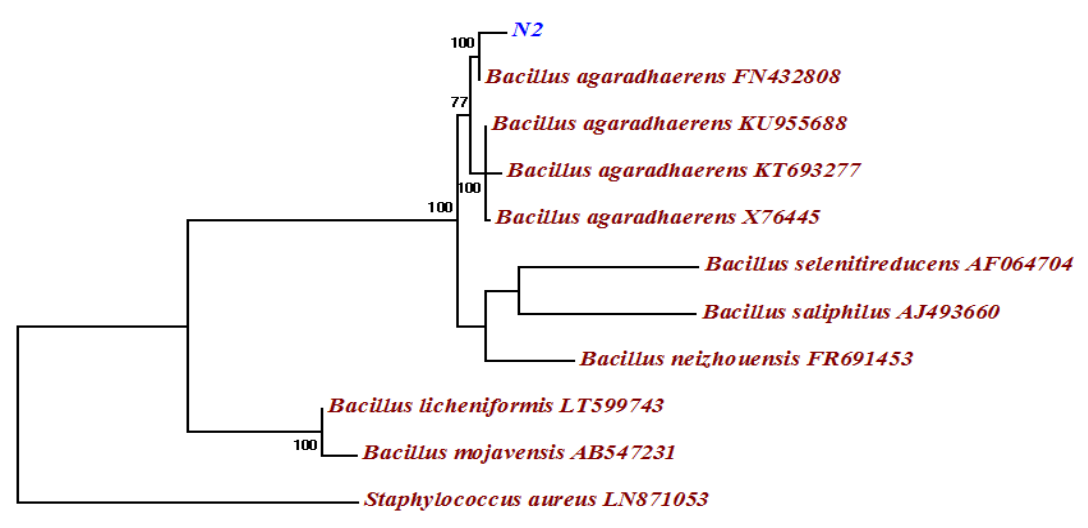

$\longmapsto$

Şekil 2. Maksimum Likelihood (ML) yöntemine göre N2 izolatı için 16S rRNA gen dizilerine dayanan filogenetik ağaç.

\section{Sonuç}

$\mathrm{Bu}$ araştırmada; Lakkaz enzimi yönünden pozitif ve mannanaz enzimi yönünden negatif olan N1 ve N2 izolatlarının, morfolojik, fizyolojik ve biyokimyasal özelliklerine ve 16S rRNA diziliş analizine göre Halomonas stevensii N1 ve Bacillus agaradhaerens N2 türüne ait olduğu belirlendi.

Bu çalışmada, N1 izolatı Halomonas stevensii, N2 izolatı ise Bacillus agaradhaerens olarak teşhis edilip ekstraselüler hidrolitik enzim aktivitelerine bakılmıştır. Bu tezde elde edilen ilk sonuçlar ile bakterilerden endüstriyel kullanım potansiyeli olan enzimler elde edilmiştir. N1 ve N2 izolatı mannanaz ve katalaz aktivitesi göstermiştir. Gelecekteki çalışmalar, bu enzimlerin bir diğer karakterizasyonu, termostabilite, raf ömrü ve bu özelliklerin iyileştirilmesi konularında araştırmalar yapılarak, endüstriyel ölçekte önemli enzimlerin daha büyük ölçeklerde üretilmesinde kullanılabilir. Buna ek olarak, bu çalışmada izole edilen bakteri türlerinde (varsayılan genler) bazı enzim genleri bulunmamaktadır. Dolayısıyla, bu varsayılan enzimler için yapılabilen klonlama çalışmaları ile yeni enzimleri keşfetmek ve ülkemiz için patent almak için bir firsat vardır. Bu tür çalışmalar ülkemizin enzime olan dişa bağımlılığından kurtaracak ve ekonomimize ciddi bir değer katacaktır.

\section{Kaynakça}

Arık, B., Körlü, A. E., \& Duran, K. (2008). Lakkaz Enzimlerinin Tekstilde Kullanım Alanları. Tekstil Teknolojileri Elektronik Dergisi, 2(2).

Awla, F., Özdemir, K., Ertaş, M. (2017). Irak-Erbil'den Alınan Bazı Toprak Numunelerinden Streptomyces Bakterilerinin İzolasyonu, Ekstraselüler Hidrolitik Enzim Kabiliyetlerinin Belirlenmesi ve 16S rDNA Analizi. Yüzüncü Yıl Üniversitesi Fen Bilimleri Enstitüsü Dergisi, 22(2), 132-138.

Busse, H. J., Denner, E. B. M., and Lubitz, W. (1996). Classification and identification of bacteria: current approaches to an old problem. Overview of methods used in bacterial systematics. J. Biotechnol. 47, 3-38. doi: 10.1016/0168-1656(96)01379-X.

Chandra, R., Chowdhary, P. (2015). Properties of bacterial laccases and their application in bioremediation of industrial wastes. Environ Sci Process Impacts, 17(2), 326-42. doi: 10.1039/c4em00627e.

Chen, F., Sun, J., Han, Z., Yang, X., Xian, J., Lv, A., Hu, X., Shi,H. (2019). Isolation, Identification and Characteristics of Aeromonas veronii From Diseased Crucian Carp (Carassius auratus gibelio). Front. Microbiol. 10, 2742. doi: 10.3389/fmicb.2019.02742.

Demiralp, B., Büyük, İ., Aras, S., Cansaran-Duman, D. (2015). Lakkaz enziminin endüstriyel ve biyoteknoloji alanında kullanımı. Türk Hijyen ve Deneysel Biyoloji Dergisi. Turk Hij. Den. Biyol. Derg., 72(4), 351-68.

Dhawan, S., Kaur, J., 2007. Microbial mannanases: an overview of production and applications. Crit. Rev. Biotechnol. 27(4): 197-216

Feng, Y., He, Z., Ong, S.L., Hu, J., Zhang, Z., Ng, W.J., 2003. Optimization of agitation, aeration, and temperature conditions for maximum beta-mannanase production. Enzyme and Microbial Technology. 32: 282-289.

George, M.G., Julia, A.B., Timothy, G.L., 2005. Bergey's manual of systematic bacteriology. In Volume 2: The Proteobacteria (pp. 552556). Springer-Verlag, Berlin.

Horikoshi, K. (1999). Alkaliphiles: some applications of their products for biotechnology. Microbiol. Mol. Biol. Rev., 63, 735-750.

Ibrahim, A. S. S., Al-Salamah, A. A., Elbadawi, Y. B., El-Tayeb, M. A., Almaary, K. S., \& Elagib, A. A. (2016). Alkaline protease from a new halotolerant alkaliphilic Bacillus agaradhaerens strain ak-r isolated from egyptian soda lakes . Bioscience Journal, 32(6). https://doi.org/10.14393/BJ-v32n1a2016-33251.

Jukes, T. H., Cantor, C. R. (1969) Evolution of protein molecules. In Munro HN, editor, Mammalian Protein Metabolism, pp. 21-132, Academic Press, New York.

Khalikova E., Somersalo S., Korpela T. (2019) Metabolites Produced by Alkaliphiles with Potential Biotechnological Applications. In: Advances in Biochemical Engineering/Biotechnology. Springer, Berlin, Heidelberg. DOI: https://doi.org/10.1007/10_2019_96. 
Kim, K. K., Lee, K. C., Oh, H. M., Lee, J. S. (2010). Halomonas stevensii sp. nov., Halomonas hamiltonii sp. nov. and Halomonas johnsoniae sp. nov., isolated from a renal care centre. Int. J. Syst. Evol. Microbiol. 60(Pt 2):369-77. Epub 2009/08/05. 10.1099/ijs.0.021105-0.

Kumar, S., Nei, M., Dudley, J., Tamura, K. (2008). MEGA: a biologist-centric software for evolutionary analysis of DNA and protein sequences. Briefings in bioinformatics, 9(4), 299-306. https://doi.org/10.1093/bib/bbn017.

Lane, D. J., Pace, B., Olsen, G. J., Stahl, D. A., Sogin, M. L., \& Pace, N. R. (1985). Rapid determination of 16S ribosomal RNA sequences for phylogenetic analyses. Proceedings of the National Academy of Sciences, 82(20), 6955-6959.

Nikiforov, Y. E., \& Howles, P. N. (2001). Polymerase chain reaction. In Morphology Methods (pp. 181-207). Humana Press.

Öğün, E., Özdemir, K., Özok, N., Ertaş, M, Öztürk, F. (2018b). Sarıkamış(KARS) Yöresinde Pinus sylvestris L. Orman Topraklarından İzole Edilen Ektraselular Lakkaz Üreten Bacillus megaterium S1 İzolatının Karakterizasyonu. Yüzüncü Yıl Üniversitesi Fen Bilimleri Enstitüsü Dergisi, 23(1), 79-86.

Özdemir, K., Öğün, E., Ertaş, M., Özok, N. (2018a). Kozluk (Batman) Tuzla Gözü Tuzlasından İzole Edilen Ektraselüler İnulinaz Enzimi Üreten Salinivibrio T1 İzolatının Karakterizasyonu. Yüzüncü Y1l Üniversitesi Fen Bilimleri Enstitüsü Dergisi, 23(1), 60-68.

Sharef, G., Özdemir, K., Ertaş, M. (2018). Awa Sppi Nehri’nden (Süleymaniye-Irak) İzole Edilen Acidithiobacillus Cinsi Bakterilerin Ektraselüler Hidrolitik Enzim Üretme Kabiliyetlerinin Belirlenmesi ve 16S rDNA Analizi. Commagene Journal of Biology, 2(1), 17-20. DOI: 10.31594/commagene.392847.

Shekher, R., Sehgal, S., Kamthania, M., \& Kumar, A. (2011). Laccase: microbial sources, production, purification, and potential biotechnological applications. Enzyme research. Volume 2011, Article ID 217861, 11 pages doi:10.4061/2011/217861.

Singh, G., Bhalla, A., Kaur, P., Capalash, N., Sharma, P. (2011). Laccase from prokaryotes: a new source for an old enzyme. Reviews in Environmental Science and Bio/technology, 10(4), 309-326.

Van den Burg, B. (2003). Extremophiles as a source for novel enzymes. Curr. Opin. Microbiol. 6(3), 213-8. DOI: 10.1016/s13695274(03)00060-2.

Wiseman, A. (ed.) (1987). Handbook of Enzyme Biotechnology. (2nd ed.) Ellis Horwood Ltd., UK. 